\title{
A Seventeenth-Century Japanese Map of the World
}

\section{Author(s): E. Heawood}

Source: The Geographical Journal, Vol. 52, No. 5 (Nov., 1918), pp. 303-308

Published by: geographicalj

Stable URL: http://www.jstor.org/stable/1779434

Accessed: 20-06-2016 04:55 UTC

\section{Your use of the JSTOR archive indicates your acceptance of the Terms \& Conditions of Use, available at}

http://about.jstor.org/terms

JSTOR is a not-for-profit service that helps scholars, researchers, and students discover, use, and build upon a wide range of content in a trusted digital archive. We use information technology and tools to increase productivity and facilitate new forms of scholarship. For more information about JSTOR, please contact support@jstor.org.

The Royal Geographical Society (with the Institute of British Geographers), Wiley are collaborating with JSTOR to digitize, preserve and extend access to The Geographical Journal 
of independence on the part of the Magyars. All the same I sincerely hope that.Rumanian aspirations may be realized.

As regards the Dobrogea position, may I be permitted to point out that I did not at all overlook the possible advantage to Bulgaria of the occupation of iterritory south of the Danube and directly commanding the weak strategic position afforded by the junction of Wallachia and Moldavia. But there are obviously two ways of regarding the military possibilities which might arise from the advance of a hostile force across the Danube at this point. It might, of course, happen as Colonel Rosetti suggests, that such a force would be capable of dividing the defensive armies of Wallachia from those of Moldavia, and of defeating them separately. On the other hand, provided that the military strength of Wallachia were fully developed independently of Moldavia, it appears to me that the dividing force would find itself in the awkward predicament of being threatened on both flanks, with the Danube behind it. Colonel Rosetti maintains that Wallachia would have to be abandoned in face of such an advance on the part of Bulgaria. Here I fail to follow him. Why should not Wallachia be rendered capable of defending herself against any such contingency?

\section{A SEVENTEENTH-CENTURY JAPANESE MAP OF THE WORLD}

VALUABLE gift has been made to the Society's collections by Mr. A Post Wheeler, lately attached to the United States Embassy at Tokyo, in the form of an excellent reproduction, made under his instructions, of a Japanese map of the World painted in colours on a bed-screen about 1653. The map is of much interest as a specimen of native Japanese work at a time when European knowledge was first gaining a footing in that Empire, and particularly so when compared with the Chinese World-map of Matteo Ricci described in the Journal for October I9r 7, although its smaller size, later date, and comparative lack of detail hardly entitle it to so important a place among the cartographical monuments of the past.

The screen on which the map is painted is one of a pair, the other containing a detailed map of the Japanese islands, in which every province is delimited, and the name of each daimyo given with his territorial boundary, while on the reverse side is a list of the nengo (chronological eras) of Japan. It is to be wished that this too may be made accessible by a reproduction, for its interest is bound to be great as a sample of early Japanese cartography of their own country. Mr. Wheeler says that the screens were certainly painted in the era of Sho-o ( $165_{2-55}$ ), since the list of nengo ends with that era and the then ruling emperor 
(Go-Komyo) is spoken of as "present reigning." That they were originally owned by the Daimyo of Echizen province (the modern FukuiKen) is shown by the fact that for that province alone the Daimyo's name is not given-it being no doubt thought superfluous to mention his name in his own domain. They are now the property of Mr. Takashi Masuda of Tokyo. Incidentally Mr. Wheeler mentions that two similar pillowscreens (makura biobu), which were used in the sleeping-chamber of Tokugawa Iyemitsu, third Shogun, are preserved in the Nikko temple.

The map of the World can be seen at first sight to be founded on European models, as such a map must obviously have been at the date in question, if based on anything better than guesswork for regions at a distance from Japan. We know moreover that such European sources were used in Japan at the time, though we are not aware that any map of so early a date has yet been reproduced. Describing his second journey to the Japanese Court in I692, Kaempfer ('History of Japan,' Maclehose's reprint, vol. 3, p. I77) tells us that he was shown specimens of Japanese maps then in use. He says: "Then two maps were brought in, one of which; was without the names of countries and places, otherwise well enough made, and in all likelihood copied after an European map. The other was a map of the whole world, of their own making, in an oval form [no doubt after the model of the oval maps of Ortelius], and marked with the Japanese Kattakanna characters." This second map was of interest from its representation of the countries beyond Japan to the north, still almost unknown to Europeans. Von Siebold, in his monumental work on 'Nippon,' published in $\mathbf{r} 852$, has an interesting section (Band $\mathrm{I}$, Abt. I, pp. I2 2-I45) on the history of the discovery by the Japanese of their own and neighbouring countries, which throws some light on the general development of geography in the Japanese Empire. As in China, scientific geography had its beginnings only after the arrival of Europeans, though rough coast-charts, town-plans, and local maps of a pictorial or diagrammatic character were previously in use. European science here made its way more slowly than in China, in spite of the fact that the Jesuits began their labours thirty years sooner in Japan than in the latter country. According to Von Siebold it is to the Chinese works of Ricci and his coadjutors that most of the progress eventually realized is to be ascribed. In the early part of the seventeenth century the missionaries had a. hard struggle to maintain their own position, and on the final banning of Christianity and expulsion of the Spaniards and Portuguese it was only the commercial intercourse still permitted to the Dutch that afforded a restricted channel for the diffusion of European knowledge.

This being the case it is only to be expected that the Japanese author of a map drawn about 1653 would base his work principally on Dutch models, more especially as Dutch cartographers had come still more to the front by 1650 than in Ricci's time. And this is quite borne out by Mr. Wheeler's map. Looked at broadly there is a strong general resemblance 
between it and Ricci's map, both alike being based on the works of the Dutch-Flemish school, but points of detail emphasize the influence of the Dutch element. As with Ricci's map, no one European map can be said to have supplied the model, but we have rather the result of comparison and compilation from separate maps-an evidence of the interest in world-geography taken at the time in some circles at least among the Japanese. For certain parts of the map, however, the adherence to older models, in preference to those followed for the greater part, is something of a puzzle.

The map is rectangular, and, including a border of about $\frac{3}{4}$ inch, measures $39 \times 16 \frac{3}{8}$ inches. The sea is coloured a rich deep blue, and certain territorial divisions of the lands, and islands, are also variously coloured, the reason for their selection being not obvious. Lakes and rivers are coloured blue, though the rivers are often but slightly indicated, and many even of the first importance are altogether omitted. No complete degreenet is shown, the only lines drawn being the equator and tropics, with the Arctic circle shown much less prominently, and an indistinct trace of one other parallel in about the latitude of England. Strong vertical lines divide the map into six compartments (possibly those of the screen itself), but are hardly to be taken for meridians. The form might seem to suggest that the map is drawn on Mercator's projection, though this, after its first use by Mercator for his map of $\mathrm{I}_{5} 69$, found no great favour with cartographers for a considerable time. But the relative dimensions in latitude and longitude show at once that the Mercator scale of latitude was not employed. The positions of the tropics and Arctic circle relatively to the equator are precisely those entailed by the use of equidistant parallels, which we may therefore conclude to have been adopted. The filling of the whole rectangle by the map seems to exclude the possibility that the model was on the oval projection of Ortelius, yet the shape of the continents in some ways rather suggests that such was employed. The representation of South America, with the west coast sloping strongly downwards towards the right, as it does in the oval maps, is difficult to account for on the supposition of vertical meridians. Yet we find a somewhat similar deviation from the true direction in one of Ortelius's own maps-that of the Pacific engraved in 1589 -where South America would almost seem to have been superimposed as a whole on the degree-net without any allowance for the reversed trend of the meridians in a map in which this continent lies on the right instead of, as in the World-map, on the left-hand side. Something similar may have occurred in the Japanese map. On the other hand, there may in both cases be merely a reversion to the form of South America to be seen in various maps of the earlier part of the sixteenth century. However this may be, we may pretty confidently regard our map as constructed on the projection now known as the "Simple Cylindrical." In this respect it agrees with Peter Plancius's great map of 1592 , now at Valencia, 
never yet reproduced in modern times, which seems to be the only important printed World-map of the period in which this projection was used. In the Japanese map, it should be noted, the arrangement of the land-masses within the framework is that adopted in Europe, there being no attempt to emphasize the importance of the draughtsman's native country by bringing this into the middle zone of the map.

The complex interrelation of the best European maps of the period makes it difficult to say which, if any, has exercised the greatest influence on the present specimen, but a search for determining features is not wholly without result. The most critical seems to be the representation of the north-east of North America, from the St. Lawrence to the Arctic region north of Hudson Bay, as composed entirely of an archipelago of large islands. This is to be found in none of the atlas-maps of the time, but it does occir in one or two single Dutch maps, namely on Allardt's revised edition (1640) of Franciscus Hoeius's world-map of about 1600, and on Blaeu's map of 1605 -both of which appear to be mainly based on Plancius.* In other respects, too, there is a close agreement with Hoeius's map, which however, unlike Plancius's, was drawn on Mercator's projection. Special points of resemblance are: (I) The shape of the Gulf of California, with the widening to the east at its head; (2) the representation of the river-system of South America, with a central lake discharging in three directions : the idea recurs in other maps, but there is most minute agreement between Hoeius and the Japanese map; (3) the drawing of the Solomon Islands and New Guinea, the latter joined to the great southern continent, as in Ortelius's 'America' of 1589 . The junction is hinted at in other maps too, and singularly enough the resemblance in this respect is most marked between the Japanese map and Ricci's, the influence of which is perhaps to be traced also in other parts of the map, where the Dutch model is not exactly followed.

Points of general agreement with Dutch and other maps founded on Mercator are: the representation of northern and north-eastern Asia (with the Tazata Island of Pliny), and the insertion of the Obi and its gulf, with the lake (Kithay of other maps) in which it was supposed to originate; the drawing of the lakes in the interior of China after the pattern set by Ludovicus Georgius in his map engraved by Ortelius in I 584 , and also of the fabulous Lake Chiamay in northern Indo-China, giving birth to four great rivers, which had so great a vogue for over a century. The line of the great wall of China is to be recognized by the curve given to it also in the European maps of the time; it too made its first appearance in Georgius's map in Ortelius. The great lakes of Central Africa are shown, though here as elsewhere the rivers, including even the Nile, are omitted.

The main points of divergence from maps of the Hoeius type consist

* The archipelago in question does not appear in Plancius's smaller map of $\mathbf{1 5 9 4}$ in Linschoten. 
largely in the retention of certain features characteristic of the earlier maps of Mercator and Ortelius-most of them also shown by Ricci. The general shape of North-West North America recalls both Ortelius and Ricci. In the interior Mercator's great lake of fresh water, connected with the Arctic Ocean by a river, is to be seen, as well as his three smaller lakes to the east, belonging to the St. Lawrence system. Mercator's four great Arctic islands are still shown, and there is no recognizable representation of Novaya Zemlya, correctly shown on all the later Dutch maps. In the south we still see the Java Minor of Polo (really Sumatra) placed, as by Mercator, in the great gulf of the southland south of the Malay Archipelago. The incorrect drawing of South America already referred to is another point of divergence, as is also the general looseness of copying of the European coastlines (noticeable too in Ricci) and the tendency to exaggerate the coast indentations generally, by which the shape of the lands, and particularly of the islands, suffers considerably. Lastly, as was to be expected, there is a great improvement in the outlines of Korea and of the Japanese Islands. This merits brief discussion in a special paragraph.

One special feature not yet mentioned is the supply of small inset maps of the northern and southern hemispheres. Such were already given in ${ } 59^{2}$ by Plancius, who in his address "Geographiæ Studioso" speaks of the insets definitely as of hemispheres. Hoeius gives insets of the northern and southern regions, but these extend only to $50^{\circ}$. In spite of their small scale the Japanese insets show a somewhat unusual care to make the outlines conform to those of the main map.

The improvement in the drawing of Korea and the Japanese Islands might suggest to some that native sources had supplied the means of correction, but this is not likely. For the topography of the interior such native material did exist, though based, as Von Siebold says, on mere compass work, and making no pretence of laying down places with exact geographical co-ordinates. But such early Japanese maps as are available give little indication of precision in the drawing of the form of the islands. One reproduced by Teleki in his great work on the historical cartography of Japan (Plate I 2), though dating from so late as the beginning of the eighteenth century, makes no attempt to show the characteristic curve of the island group, which instead forms a nearly straight band running due east and west. But there were in existence at the time European charts which gave quite a good approximation to the true shape of the islands. Even in 1595 Ortelius had been able to include in his atlas a map of Japan (by L. Teisera) which erred chiefly in the east to west direction given to the main axis of the group, and was little inferior to Mr. Wheeler's map except in the misrepresentation of Korea as an island and the omission of Yezo. Ricci too gave a good general idea of the shape and relative position of the islands. By the middle of the seventeenth century the activity of Dutch navigators had 
further added to precise knowledge, and the relatively advanced state of this about the time in question is well shown by the anonymous Portu guese chart in the Paris National Library reproduced by Teleki in his collection (Plate 5, No. I). These early nautical charts are in fact-as was so often the case-far better than many of the later efforts of landsmen, as can be seen by a comparison of the various maps given by Teleki. It is therefore likely that the Japanese, when after the expulsion of the missionaries they began making the first crude maps of their own islands, availed themselves of the European material ready to their hand, rather than that they themselves executed surveys to supply the framework for the topographical detail. But conclusions on this head would no doubt be greatly helped and would also be of more value could we study the largescale map of Japan shown on the second of the pair of bed-screens.

E. HEAWOOD.

\section{NOTES ON THE EARLY HISTORY OF THE MARINER'S COMPASS}

\section{Esposito}

\section{I.-Brunetto Latino and Roger Bacon.}

RECENT writer in the Irish periodical Studies,* Prof. A. J. Rabilly,
dealing with certain publications on Roger Bacon, makes the following statement : "A reliable contemporary account of Bacon's real work at Oxford would be a valuable addition to our knowledge. Hence I venture with much diffidence to quote a passage which (so far as I know) has remained unnoticed and unknown. In the Monthly Magazine for 1802 there was published the translation of some letters from Brunetto Latino $\uparrow$ to Guido Cavalcanti describing his impressions of a visit to England. The letters are exceedingly interesting and deserve a careful investigation from students of Dante and of English literature. The discussion of their authenticity hardly falls within the competence of the present writer, but there is strong internal evidence of genuineness. Until proof is forthcoming there seems no reason to doubt the authenticity of the following vivid and strangely neglected description of Bacon at Oxford as seen by a sympathetic and cultured visitor." Then follows a long extract from the eighth of these letters, in the course of which occurs the following passage (loc. cit., pp. 254-55): "He (i.e. Bacon) further showed me (Brunetto Latino) a black ugly stone called a magnet which has the surprising property of drawing iron to it; and upon which if a needle be

* An Irish Quarterly Reviezv of Letters, Philosophy, and Science, 3, September 1914, pp. 252 seq.

$\dagger$ Latino is more correct than the common Latini, cf. Gaspary, 'Early Italian Literature,' translated by Oelsner (Igor), pp. 367-8. 